\title{
PELATIHAN PENGENALAN ISO 9001: 2015 BAGI ALUMNI ANALIS KIMIA UNDIKSHA
}

\author{
I.M. Gunamantha ${ }^{1}$, I.K Lasia ${ }^{2}$, P.L.P Kritiyanti ${ }^{3}$ \\ 1Jurusan Kimia, Universitas Pendidikan Ganesha \\ ${ }^{2,3}$ PLP Lab Kimia,Universitas Pendidikan Ganesha \\ e-mail:md_gunamantha@yahoo.com, lasiaiketut@gmail.com, \\ lilik_putu@yahoo.com
}

\begin{abstract}
Abstrak
Pelatihan ini dirancang untuk membantu para peserta memahami esensi dari ISO 9001:2015 sebagai versi terbaru saat ini yang dikeluarkan oleh ISO dan membantu peserta memahami bagaimana menerapkannya pada kondisi aktual di lapangan. Metode kegiatan yang digunakan adalah: 1) ceramah, diskusi, dan penugasan. Kegiatan ceramah dilaksanakan secara daring dengan menggunakan apikasi zoom. Ceramah digunakan dalam penyampaian materi tentang hal-hal pokok dalam setiap klausal ISO 9001:2015 dan interpretasinya. Ilustrasi beserta contoh-contoh dukumen relevan untuk setiap klausal juga diberikan. Hasil dari kegiatan ini berdampak pada pemahaman peserta pada setiap klausal SNI ISO 9001:2015 dan mampu mampu mengidentifikasi kesenjangannya dengan sistem manajemen yang sedang diterapkan saat ini di orgaisasinya. Peserta sangat antusias mengikuti pelatihan dan sangat aktif dalam mengajukan pertanyaan ataupun kendala yang dihadapi dalam penerapan sistem ini pada organisasinya. Kegiatan ini sangat mengharapkan peserta dapat menularkan pengetahuan yang diperoleh dan berkontribusi pada penerapan ISO 9001:2005 di instansi asalnya.
\end{abstract}

Kata kunci: SNI ISO 9001:2015, Pelatihan, Ceramah, Alumni Analis Kimia

\begin{abstract}
This training is designed to help participants understand the essence of ISO 9001: 2015 as the latest version currently issued by ISO and help participants understand how to apply it to actual conditions in the field. The activity methods used are: 1) lectures, discussions, and assignments. Lecture activities are carried out online using the zoom application. Lectures are used in delivering material about the main points in each clause of ISO 9001: 2015 and their interpretation. Illustrations along with examples of relevant documents for each clause are also provided. The results of this activity have an impact on the participants' understanding of each clause of SNI ISO 9001: 2015 and are able to identify gaps with the management system currently being implemented in their organization. The participants were very enthusiastic about participating in the training and were very active in asking questions or obstacles faced in implementing this system in their organization. This activity really hopes that the participants can share the
\end{abstract}


knowledge they have acquired and contribute to the implementation of ISO 9001: 2005 in their institutions.

Keywords : SNI ISO 9001: 2015, Training, Lecturing, Chemical Analyst Alumni

\section{PENDAHULUAN}

Saat ini manusia hidup di era kualitas (mutu) (Juran and Godgrey, 1999). Mutu diukur, dianalisis, dan dibahas dimana-mana. Mutu menjadi tuntutan dari berbagai pihak baik sebagai individu, perusahaan, maupun kelompok masyarakat. Implikasinya adalah mutu akan menentukan keberhasilan bagi penyedia produk atau layanan. Dengan demikian, organisasi harus terus menerus meningkatkan mutu produk atau layanannya agar sesuai dengan keinginan pelanggan. Setiap instansi atau perusahaan yang ingin meningkatkan kinerja dan kompetensi harus memberikan perhatian penuh pada mutu produk atau jasa yang dihasilkannnya. Mutu yang baik tersebut hanya bisa dihasilkan melalui proses manajemen organisasi yang baik pula, diantaranya dengan memiliki sistem atau program-program mutu (Juran and Godgrey, 1999). Salah satu strategi organisasi untuk meningkatkan sistem manajemen mutunya adalah dengan mengadopsi standar ISO 9001 (Sari., dkk. 2017; ISO, 2016).

ISO 9001 telah mengalami revisi empat kali sejak pertama kali diterbitkan pada tahun 1987. Revisi pertama dilakukan di tahun 1994, kedua di tahun 2000, dan dan ketiga 2008 serta yang terakhir di tahun 2015. Revisi terakhir yang dilakukan oleh komite teknis ISO ini, dimulai pada pertengahan tahun 2013. Sejak saat itu ISO/TC 176 Manajemen Mutu dan Jaminan Mutu, telah menerbitkan draft revisi standar manajemen mutu untuk versi berikutnya. Revisi keempat ini selanjutnya diterbitkan pada tahun 2015 dan diharapkan dapat menjadi standar yang stabil, minimal untuk 10 tahun ke depan. ISO 9001 : 2015 mulai dipublikasikan pada pertengahan tahun 2015. Beberapa persyaratan ditambahkan pada versi 2015, hal ini semakin menyempurnakan sistem yang dimiliki oleh ISO 9001 versi 2008.

$\mathrm{Di}$ Indonesia, berdasarkan SK Kepala BSN No. 308/Kep/BSN/12/2015 tentang Penetapan Revisi 2 (dua) Standar Nasional Indonesia dimana SNI ISO 9001:2008 telah direvisi menjadi SNI ISO 9001:2015. Komite Akreditasi Nasional (KAN) telah menetapkan masa transisi untuk perubahan tersebut selama 3 (tiga) tahun. Sebagaimana standar sebelumnya, SNI ISO 9001:2015 mengadopsi secara penuh persyaratan pada ISO 9001:2015. Dengan diberlakukannya SNI ISO 9001 versi 2015 ini, maka diperlukan pula adanya peningkatan pemahaman sistem manajemen mutu sesuai persyaratan yang telah ditetapkan SNI ISO 9001:2015.

DI Indonesia pada saat ini, SNI 9001:2015 merupakan sebuah standar yang sangat populer di kalangan praktisi organisasi bisnis maupun 
nirlaba. Organisasi menggunakan standar ini untuk mendemonstrasikan kemampuannya untuk secara konsisten menyediakan produk dan layanan yang memenuhi persyaratan pelanggan dan peraturan. Ini adalah standar paling populer dalam seri ISO 9000 dan satusatunya standar dalam seri yang dapat disertifikasi oleh organisasi. Standar ini menuntut, sebuah organisasi harus menunjukkan kemampuan untuk memenuhi atau melampaui kepuasan pelanggan dalam hal fungsi produk, kualitas dan kinerja. Organisasi juga harus selalu menerapkan peraturan, standar organisasi, dan praktik terbaik mengenai proses produksi dan hasil. Oleh karena itu, sertifikasi ISO 9001 juga sangat relevan diterapkan pada instantsi pemerintah, pelayanan publik seperti rumah sakit apalagi di organisasi bisnis dimana alumni Analisis Kimia Undiksha banyak bekerja disitu.

$$
\text { Para alumni Analisis Kimia }
$$

Undiksha itu, tentu saja tidak memperoleh materi ini saat perkuliahan. Hal ini karena versi ISO 9001 ini baru diterbitkan pada tahun 2015. Oleh karena itu, untuk meningkatkan wawasan dan pemahannya, pelatihan pemahaman ISO 9001:2015 penting untuk diberikan sehingga para alumni bisa lebih banyak berkontribusi di tempat kerjanya masing-masing. Pada akhirnya diharapkan dapat meningkatkan citra lembaga di masyarakat khususnya pihak pengguna lulusan Analisis Kimia Undiksha. Selain itu, sebagai upaya untukmenjaga tali asih dan berbagi pengalaman antara program studi dengan lulusannya.
Bertolak dari situasi tersebut, pengabdian masyarakat ini dimaksudkan untuk memberikan pelatihan pengenalan tentang pemahaman sistem manajemen mutu SNI ISO 9001: 2015 bagi lulusan Program Studi Analisis Kimia Fakultas Matematika dan IImu Pengetahuan Alam (FMIPA) Universitas Pendidikan Ganesha (Undiksha) yang tergabung dalam keanggotaan Himpunan Alumni Analisis Kimia.

\section{METODE}

Pelatihan ini merupakan upaya untuk membantu mengembangkan kompetensi lulusan Program Studi Analisis Kimia dan memperoleh efektivitas kerja yang lebih meningkat dalam pekerjaannya yang sekarang. Pelatihan ini juga merupakan sarana pembinaan dan pengembangan karir alumni di tempat kerjanya saat ini. Untuk mencapai tujuan tersebut telah diidentifikasi permasalahan bahwa alumni Analisis Kimia belum mengetahui perkembangan dan memahami ISO 9001:2015. Metode yang diterapkan dalam pelatihan ini adalah ceramah, diskusi, dan tanya workshop SNI ISO 9001:2015. Materi yang diberikan dalam pelatihan ini meliputi: 1) Prinsip-Prinsip Sistem Manajemen Mutu ISO 9001:2015; 2) Ruang Lingkup ISO 9001:2015; 3) Konteks Organisai: kebutuhan dan harapan pihak-pihak yang terkait, penentuan ruang lingkup sistem dan sistem manajemen mutu beserta proses-prosesnya; 2) Peran Kepemimpinan: Fokus Pelanggan, Kebijakan, peran, tanggung jawab dan wewenang; 3) Perencanaan: Risiko dan peluang, tujuan mutu dan rencana 
untuk mencapainya serta rencana perubahan; 4) Dukungan: sumber daya, kompetensi, awareness, komunikasi, dan informasi terdokumentasi; dan 5) Operasi: perencanaan dan pengendalian operasi, persyaratan produk/jasa, desain dan pengembangan produk/jasa, pengendalian produk/jasa/proses dari pihak eksternal, produksi dan penyediaan jasa, pelepasan produk/jasa dan pengendalian hasil yang tidak sesuai. Materi-materi ini sesuai dengan klausal-klausal dalam SNI ISO 9001:2015. Seluruh kegiatan ceramah dan diskusi dilakukan secara online dengan menggunakan link zoom.

Untuk mengetahui tercapianya tujuan pelatihan ini, dilakukan evaluasi dengan meminta respon dari peserta dengan mengajukan 4 (empat) pernyataan yang disampaikan melalui group WA pelatihan yang telah dibuat sebelumnyaKelima pertanyaan tersebut sebagai berikut. Apakah materi yang disajikan dapat menambah wawasan bpk/ibu tentang sistem manajemen mutu ISO 9001:2015?; apakah penyajian materi cukup interaktif?, apakah pelatihan ini dapat membantu meningkatkan profesionalisme bpk/ibu?; dan apa saran bpk/ibu untuk pelatihan berikutnya!

\section{HASIL DAN PEMBAHASAN}

Peserta tampak antusias menjalani seluruh rangkaian kegiatan pelatihan. Sebagian besar peserta tidak memiliki dasar pemahaman terhadap sistem manajemen mutu. Namun, kesungguhan peserta dalam mengikuti pelatihan menghasilkan pemahaman yang baik tentang pemanfaatan sistem manajemen mutu ISO 9001: 2015.
Pada pelatihan kali ini hanya difokuskan pada pengenalan dan interpretasi SNI ISO 9001:2015 dan pengenalan pembuatan dokumen mutu khususnya manual mutu dan standar operasional prosedur. Selain memberikan pemahaman melalui ceramah dan diskusi, peserta juga diberikan kesempatan untuk menyampaikan hal-hal yang belum dipahami di luar sesi ceramah dan diskusi.

Mengingat materi yang disampaikan adalah versi terbaru dari ISO 9001:2015, banyak pertanyaan yang disampaikan oleh peserta mengenai hal-hal yang tidak dipahami pada saat pengajar/instruktur memberikan pelajaran. Penyampaian materi ditekankan pada pemahaman setiap klausal yang dipersyaratkan yakni dari klausal 4 hingga klausal 10 . Secara ringkas penekanan yang disampaikan untuk masing-masing klausal (ISO, 2015) adalah sebagai berikut. Persyaratan 4 terdiri dari 4 subklausal yaitu: 4.1. memahami organisasi dan konteknya, 4.2. mamahami kebutuhan dan ekspektasi dari pihak yang berkepentingan, 4.3. menetapkan lingkup dari sistem manajemen mutu, dan 4.4. sistem manajemen mutu. Maksud dari klausal ini adalah untuk memahami masalah eksternal dan internal yang relevan dengan tujuan dan arah strategis organisasi dan yang dapat mempengaruhi, baik secara positif atau negatif, kemampuan organisasi untuk mencapai hasil yang diinginkan dari sistem manajemen kualitasnya. Organisasi harus menyadari bahwa masalah eksternal dan internal dapat berubah, dan oleh karena itu, harus 
dipantau dan ditinjau. Organisasi dapat melakukan peninjauan konteksnya pada interval yang direncanakan dan melalui kegiatan seperti tinjauan manajemen. Ringkasnya, yang ditekankan dalam klausal ini adalah: Pertama, organisasi perlu menentukan masalah eksternal dan internal yang relevan dengan tujuannya, yaitu masalah apa yang relevan, baik di dalam maupun di luar, yang berdampak pada apa yang dilakukan organisasi, atau yang akan memengaruhi kemampuannya untuk mencapai tujuan. hasil yang diharapkan dari sistem manajemennya. Perlu dicatat bahwa istilah "masalah" tidak hanya mencakup masalah yang akan menjadi subjek tindakan pencegahan dalam standar sebelumnya, tetapi juga topik penting untuk ditangani oleh sistem manajemen, seperti jaminan pasar dan tujuan tata kelola yang mungkin dilakukan oleh organisasi. Kedua, organisasi juga perlu mengidentifikasi "pihak yang berkepentingan" yang relevan dengan sistem manajemen mutu (SMM) organisasi. Kelompok ini dapat mencakup pemegang saham, karyawan, pelanggan, pemasok, dan bahkan kelompok penekan dan badan pengatur. Setiap organisasi akan mengidentifikasi kumpulan unik "pihak yang berkepentingan" dan seiring waktu hal ini dapat berubah sejalan dengan arah strategis organisasi. Selanjutnya, ruang lingkup SMM harus ditentukan. Ini dapat mencakup seluruh organisasi atau fungsi yang diidentifikasi secara khusus. Setiap fungsi atau proses yang dialihdayakan juga perlu dipertimbangkan dalam lingkup organisasi jika relevan dengan SMM. Persyaratan akhir dari Klausul 4 adalah untuk menetapkan, menerapkan, memelihara, dan terus meningkatkan SMM sesuai dengan persyaratan standar. Ini membutuhkan adopsi pendekatan proses dan meskipun setiap organisasi akan berbeda, informasi terdokumentasi seperti diagram proses atau prosedur tertulis dapat digunakan untuk mendukung ini.

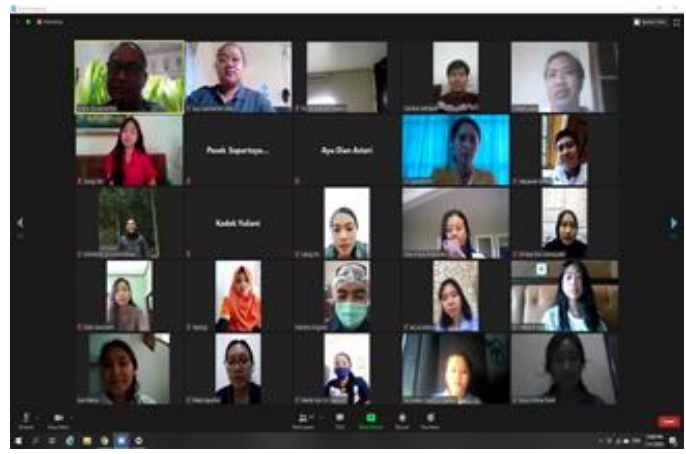

Gambar 1. Sebagian dari Peserta Pelatihan.

Klausal 5. Kepemimpinan. ISO 9001: 2015 memberikan penekanan khusus pada kepemimpinan, bukan hanya manajemen seperti yang ditetapkan dalam versi sebelumnya. Ini berarti manajemen puncak memiliki akuntabilitas dan keterlibatan yang lebih besar dalam sistem manajemen organisasi. Manajemen puncak harus memastikan bahwa persyaratan sistem manajemen diintegrasikan ke dalam proses bisnis organisasi - sistem manajemen bukan hanya sekedar bolton. Bisnis organisasi adalah aktivitas apa pun yang menjadi inti dari alasan organisasi itu ada. Selain itu, manajemen puncak juga harus menunjukkan komitmennya dengan memastikan bahwa sistem manajemen mencapai hasil yang diinginkan dan 
memiliki sumber daya yang memadai. Selain itu, harus mengkomunikasikan kepada pihak terkait bahwa sistem manajemen itu penting dan bahwa setiap orang harus berpartisipasi dalam penerapannya yang efektif. Keterlibatan manajemen puncak dalam sistem manajemen dalam versi ini eksplisit dan langsung. Kebijakan mutu juga telah diperkuat. Kebijakan mutu harus mencakup komitmen untuk memenuhi persyaratan yang berlaku dan terus meningkatkan sistem manajemen. Selain dikomunikasikan secara internal, kebijakan mutu harus tersedia untuk pihak yang berkepentingan.

Klausal 6. Perencanaan. Klausul 6 lebih menekankan pada perencanaan organisasi yang merupakan bagian integral dari bisnis organisasi. Organisasi harus terbiasa dengan risiko; konsekuensi dari suatu peristiwa dan kemungkinan kejadian yang terkait dengannya; dan bagaimana menghindari, menghilangkan, meminimalkan atau memitigasinya. Organisasi juga perlu fokus pada aspek positif - peluang untuk bisnis dan bagaimana mengoptimalkannya. Risiko dan peluang yang diidentifikasi akan mengarah pada kebijakan dan tujuan. Organisasi harus dapat mengidentifikasi dan mengikuti jalur yang jelas dari masalah dan persyaratan melalui risiko dan peluang, kebijakan dan tujuan. Klausal 7. Dukungan. Setelah memenuhi konteks, komitmen, dan perencanaan, organisasi harus melihat dukungan yang diperlukan untuk memenuhi tujuan dan sasarannya. Dukungan mencakup sumber daya, komunikasi internal dan eksternal yang ditargetkan, serta informasi terdokumentasi yang menggantikan istilah yang digunakan pada versi sebelumnya seperti dokumen, dokumentasi, dan catatan. Organisasi perlu menyediakan sumber daya yang kompeten untuk menyampaikan barang dan jasanya. Tidak ada yang baru di sini dibandingkan versi sebelumnya, kesadaran telah diperkuat sehingga sekarang setiap orang perlu mengetahui implikasi dari ketidaksesuaian dengan persyaratan sistem manajemen. Organisasi perlu mempertimbangkan kebutuhan akan komunikasi internal dan eksternal yang relevan dengan sistem manajemen apa, kapan dan dengan siapa akan berkomunikasi. Persyaratan dukungan yng terakhir (informasi terdokumentasi) menimbulkan banyak kegerahan. Di sini tidak lagi muncul istilah dokumen, dokumentasi, dan catatan. Namun demikian, persyaratan untuk pengelolaan informasi terdokumentasi bukanlah hal baru, luar biasa atau berlebihan. Satu kerangka yang akhirnya diletakkan untuk bersandar adalah gagasan bahwa setiap orang membutuhkan instruksi kerja tidak peduli seberapa berpengalaman atau seniornya mereka dalam organisasi.

Klausal 8. Apa pun yang ingin dicapai organisasi dalam bisnis, klausul 8 adalah rodanya. Manajemen proses secara keseluruhan meliputi: memiliki kriteria proses, mengendalikan proses dalam kriteria, mengendalikan perubahan yang direncanakan, dan menangani perubahan yang tidak diinginkan seperlunya. Organisasi harus merencanakan, menerapkan dan mengendalikan proses yang diperlukan untuk memenuhi persyaratan yang ditetapkannya. Ini juga terkait dengan 
penerapan tindakan yang ditentukan dalam 6.1 (tindakan untuk mengatasi risiko dan peluang) dan 6.2 (tujuan dan rencana untuk mencapainya). Organisasi diharuskan untuk: 1) menetapkan kriteria untuk proses (boleh jadi dalam instruksi kerja), 2) menerapkan pengendalian proses, sesuai dengan kriteria (boleh jadi melalui pelatihan dan kesadaran), 3) menyimpan informasi yang terdokumentasi sejauh yang diperlukan untuk memiliki keyakinan bahwa proses telah dilakukan sesuai rencana (boleh jadi dalam sistem manajemen mutunya, atau sistem manajemen yang terintegrasi), 4) mengontrol perubahan yang direncanakan dan meninjau konsekuensi dari perubahan yang tidak diinginkan, mengambil tindakan untuk mengurangi efek buruk (boleh jadi melalui manajemen perubahan proses), 5) memastikan proses yang dialihdayakan dikendalikan. Ini akan mencakup kendali dan/atau pengaruh (tergantung pada kemampuannya untuk melakukannya - ukuran pesanan, kepentingan bagi organisasi eksternal, dll.). Klausal 9. ISO 9001 mengharuskan organisasi untuk menentukan apa yang perlu dipantau dan diukur serta metode yang akan digunakan untuk menganalisis dan mengevaluasi kinerja dan efektivitas sistem manajemen mutu. Ketika mempertimbangkan kinerja dan efektivitas sistem manajemen mutu, "kinerja" adalah hasil yang terukur dari organisasi dan "efektivitas" adalah sejauh mana kegiatan yang direncanakan direalisasikan dan hasil yang direncanakan tercapai. Ketika menentukan yang perlu dipantau dan/atau diukur, organisasi harus mempertimbangkan tindakan yang diperlukan dalam klausa lain, seperti untuk menetapkan sistem manajemen mutu dan prosesnya (4.4), sasaran mutu (6.2.1), perencanaan dan kontrol operasional (8.1), kepuasan pelanggan (1.2), analisis dan evaluasi (9.1.3), audit internal (9.2) dan tinjauan manajemen (9.3). Organisasi kemudian harus menentukan bagaimana pemantauan, pengukuran, analisis dan evaluasi akan dilakukan, dan sumber daya (7.1.5) yang akan dibutuhkan. Organisasi juga harus memutuskan informasi terdokumentasi apa yang perlu disimpan sebagai bukti hasil pemantauan, pengukuran, analisis dan evaluasi. Informasi yang terdokumentasi ini biasanya merupakan informasi terdokumentasi yang sama yang diperlukan dalam klausul ISO 9001 lainnya, seperti yang untuk tinjauan manajemen. Klausal 10. Maksud dari klausal ini adalah untuk memastikan bahwa organisasi menentukan peluang untuk perbaikan, serta rencana dan benar-benar mengimplementasikan tindakan untuk mencapai hasil yang diinginkan dan untuk meningkatkan kepuasan pelanggan. Perbaikan dapat membantu organisasi untuk tetap memenuhi persyaratan dan harapan pelanggan dengan meningkatkan produk dan layanannya, memperbaiki atau mencegah efek yang tidak diinginkan, dan meningkatkan kinerja dan efektivitas sistem manajemen mutu. Ada berbagai metode untuk melakukan peningkatan, seperti: a) mengambil tindakan untuk menghindari terulangnya ketidaksesuaian; b) kegiatan perbaikan berkelanjutan kecil yang dilakukan dalam proses, produk, 
atau layanan yang ada; c) proyek yang dapat menyebabkan perubahan signifikan pada proses yang ada, implementasi proses baru, produk atau layanan, atau pengenalan teknologi atau inovasi baru yang mengganggu. Persyaratan untuk tindakan korektif (10.2) membantu untuk menentukan dan menghilangkan penyebab ketidaksesuaian, untuk mencegah terulangnya kembali. Peningkatan berkelanjutan (0.3) harus dilakukan untuk meningkatkan kinerja dan menerapkan solusi yang disepakati yang dimaksudkan untuk mencapai manfaat positif. Tindakan peningkatan dapat dilakukan pada proses, produk dan layanan serta pada sistem manajemen mutu.

Pada akhir penyajian, hampir semua peserta memberikan ucapan terima kasih atas kesempatan yang diberikan oleh pelaksana kegiatan untuk mengikuti pelatihan ini. Selain itu, mereka juga merasakan lebih terbuka pemahamannya terhadap maksud dari setiap klausal dalam persyaratan ISO 9001:2015. Hal ini ditunjukkan dari respon peserta terhadap pertanyaan yang diajukan pada akhir pelatihan. Seluruh peserta menyatakan bahwa pelatihan ini telah menambah wawasannya tentang ISO 9110:2015 serta akan sangat membantunya dalam meningkatkan profesionalismenya. Peserta juga diminta untuk mengisi checklist untuk mengetahui posisi institusinya saat ini dalam kesiapan penerapan ISO 9001:2015. Analisis kesenjangan (gap analysis) ini dilaukan untuk mengetahui hal-hal apa saja yang telah dimiliki oleh perusahaan (dokumen-dokumen terkait) sistem manajemen mutu ISO 9001:2015.
Dengan carapenyajian materi seperti itu, peserta juga mengemukakan bahwa penyampaian materi sangat detail. Di sisi lain, pelatihan seperti yang biasanya berbayar, melalui kegiatan ini, mereka peroleh secara gratis. Kami juga memberikan sertifikat kepada setiap peserta. Sertifikat disampaikan secara elektronik. Peserta juga mengungkapkan bahwa yang sudah diperoleh akan sangat membantu dalam uapaya meningkatkan profesionalismenya.

Semua materi pelatihan diberikan dalam bentuk teori dan pengenalan dokumen mutu. Adapun praktek pembuatan SOP dilakukan di instansi masing-masing, namun hasilnya dikirim via email dan diberikan masukan oleh penyaji. Selain dapat meningkatkan pemahaman peserta terhadap persyaratan ISO 9001:2015, pelatihan ini juga telah memberikan manfaat lain yakni sebagai wahana tukar informasi dan pengalaman terkait dengan sejauhmana sistem ini telah diadopsi di instansi masing-masing. Dengan memperhatikan latar belakang peserta maka dari hasil yang diperoleh dapat dilihat bahwa para peserta dapat memahami materi yang diberikan dengan cepat.

Pada akhir pelatihan, peserta diminta memberikan komentar atas pelaksanaan kegiatan pelatihan ini. Sebagian besar peserta menilai bahwa pelaksanaan pelatihan sangat baik dan sangat relevan dengan kebutuhan di institusinya masing-masing. Selama ini, hanya karyawan tertentu dari instansinya yang diberikan kesempatan untuk mengikuti pelatihan ISO 9001, mengingat biaya pelatihannya yang cukup besar. Namun, pada saat ini 
mereka dapat mengikutinya secara gratis. Semua peserta juga berpendapat bahwa hasil pelatihan ini sangat bermanfaat untuk kegiatan instansi mereka di masa mendatang. Ketika diminta untuk mengajukan saranya untuk pelatihan-pelatihan yang diperlukan, seluruh peserta berharap diadakannya pelatihan lanjutan seperti penyusunan dokumen dan audit mutu.

\section{KESIMPULAN}

Berdasarkan identifikasi dan perumasan masalah, tujuan kegiatan, serta dari hasil dan pembahasan dapat disimpulkan bahwa: (1) Pelatihan sistem manajemen mutu ISO 9001:2015 dapat meningkatkan pemahaman, wawasan, dan pengalaman peserta; (2) Pelatihan sistem manajemen mutu ISO 9001:2015 dapat membantu peserta untuk melakukan gap analisis antara kondisi yang ada di institusinya saat ini dengan tuntutan persyarata ISO 9001:2015; dan (3) Pelatihan sistem manajemen mutu ISO 9001:2015 dapat melengkapi kompetensi peserta.

\section{DAFTAR PUSTAKA}

ISO. 2015. ISO 9001:2015 Quality management systems Requirements. Geneva, Switzerland.

ISO. 2016. Quality management systems - Guidelines for the application of ISO 9001:2015. Geneva, Switzerland.

Juran and Godgrey. 1999. Juran's quality handbook. McGraw-Hill.

Sari Y, Wibisono E, Wahyudi R.D, and Lio Y. 2017. From ISO 9001:2008 to ISO 9001:2015: Significant changes and their impacts to aspiring organizations. IOP Conf. Series: Materials Science and Engineering 273 (2017) 012021. 